PRZEGLĄD NAUK HISTORYCZNYCH 2018, R. XVII, NR 2

http://dx.doi.org/10.18778/1644-857X.17.02.08

\title{
Recepcja publicystyczna Dziejów gtupoty w Polsce. Pamfletów dziejopisarskich Aleksandra Bocheńskiego
}

Streszczenie. Dzieje głupoty w Polsce. Pamflety dziejopisarskie były najważniejszą publikacją Aleksandra Bocheńskiego. Stanowiły także jedną z najbardziej reprezentatywnych refleksji dla powojennego nurtu realizmu politycznego w Polsce. Recepcja publicystyczna pierwszego wydania tej książki w latach czterdziestych XX w. dowodziła niepopularności tez w niej zawartych. Krytyka insurekcyjnych nurtów polityki polskiej dokonana przez publicystę spotykała się ze sprzeciwem zarówno marksistów, bezpartyjnych intelektualistów w kraju, jak i środowisk emigracyjnych. Chociaż zazwyczaj rozumiano motywy koncepcji Bocheńskiego, odrzucano je jako: służące komunistom, sprzeczne $z$ doktryna marksistowska bądź pozbawione fundamentu moralnego. Opinie te stanowia istotny przyczynek zapatrywań polskiej inteligencji na problematykę politycznego realizmu u progu Polski Ludowej.

Słowa kluczowe: Aleksander Bocheński, historiografia, publicystyka, realizm polityczny

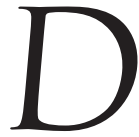

zieje głupoty w Polsce. Pamflety dziejopisarskie Aleksandra Bocheńskiego, opublikowane po raz pierwszy w połowie 1947 r., stanowia w polskiej myśli politycznej jeden z najbardziej reprezentatywnych przykładów realistycznego oglądu przeszłości naszego kraju. Niemniej publikacja ta, obok osi dotyczacej refleksji nad dziejami Polski w XVIII i XIX w. oraz krytyki historyków i publicystów propagujących szkodliwe zdaniem

${ }^{*}$ Wydział Humanistyczny, Instytut Historii, Zakład Historii Najnowszej, e-mail: ariel.k.orzelek@gmail.com. 
Bocheńskiego tendencje polityczne, zawiera także czytelne odniesienia do współczesności. Książka była dla publicysty instrumentem propagowania konieczności redefinicji rozpowszechnionej w polskiej myśli politycznej postawy negacji wobec ugody ze wschodnim sasiadem. Pisana była w latach II wojny światowej ${ }^{1}$, toteż wpływ na nią miało przekonanie autora o totalnej klęsce dotychczasowej polityki polskiej oraz o tym, że to Moskwa stanie się czynnikiem, który zadecyduje o przyszłości narodu polskiego ${ }^{2}$.

Dodać należy, że chociaż Bocheński w 1939 r. deklaratywnie wsparł antyniemiecki zwrot w polityce zagranicznej Józefa Bec$\mathrm{ka}^{3}$, to w swej międzywojennej publicystyce był rzecznikiem „Polski mocarstwowej”. Wzywał do prewencyjnej agresji na Zwiąek Sowiecki w celu urzeczywistnienia wizji prometejskiej, co wymagało przyjaznych stosunków $z$ Niemcami ${ }^{4}$. Po wybuchu wojny był natomiast zwolennikiem porozumienia $z$ III Rzesza, w celu zahamowania wyniszczającej naród polityki represji. Obserwacja zwycięstw Armii Czerwonej, przekonanie, że zachodni sojusznicy pozostawia ziemie polskie w gestii Józefa Stalina, skłoniły go, około 1943 r., do refleksji nad koniecznościa porozumienia polskiej inteligencji $z$ komunistami polskimi i sowieckimi ${ }^{5}$. Już wiosna 1945 r. w Krakowie na czele grupy intelektualistów o konserwatywnych pogladach prowadził rozmowy $z$ Jerzym Borejsza na temat powołania katolickiego periodyku, afirmującego pojałtańską rzeczywistość, i utworzeniu wokół niego politycznej grupy. Koncepcja ta zbiegła się $z$ inicjatywą Bolesława Piaseckiego i jej została podporządkowana ${ }^{6}$.

${ }^{1}$ List Aleksandra Bocheńskiego, 20 X 1943, Archiwum Państwowe w Lublinie [dalej: APL], Archiwum Łosiów z Niemiec [dalej: AŁN], sygn. 463, k. 10; List Aleksandra Bocheńskiego do Stanisława Łosia, Ponikwa 10 XI 1943, ibidem, k. 11; Nie widzę wzrostu racjonalnych postaw... Z Aleksandrem Bocheńskim $w$ 85-lecie urodzin rozmawia Karol Pastuszewski, „Kierunki” 1989, nr 33, s. 7.

2 A. Boch eńs ki, Dzieje głupoty w Polsce. Pamflety dziejopisarskie, Warszawa 1947.

${ }^{3}$ Id e m, Zygzakiem przez prasę. Prasa polska po hańbie czeskiej, "Polityka” 1939, nr 6, s. 8; id e m, „Amocklauf”, „Polityka” 1939, nr 15, s. 1.

4 I d e m, O imperialiźmie, o Skiwskim i o sprawie żydowskiej, „Polityka” 1938, nr 9, s. 3.

${ }^{5}$ Id em, Wędrówki po dziejach przemysłu polskiego, cz. 2, Warszawa 1969, s. 256; Motywy i postawy [Wypowiedź Aleksandra Bocheńskiego], „Kierunki” 1970, $\mathrm{nr} 48$, s. 8.

${ }^{6}$ R. Mozgol, Ryzykowna gra. Jak Aleksander Bocheński przyczynił się do powstania Dziś i Jutro, „Biuletyn Instytutu Pamięci Narodowej” 2007, nr 4, s. 84-92; „Moje spotkanie z Bolesławem Piaseckim - rozmowa z Aleksandrem Bocheńskim 
Dzieje głupoty w Polsce, które, co charakterystyczne, nie spotkały się z aprobatą w środowisku „Dziś i Jutro” i dzięki pomocy Stefana Kisielewskiego ukazały się w wydawnictwie „Panteon”, stanowiły w okresie 1945-1956 najobszerniejsza i najważniejsza publicystyczną wypowiedź Bocheńskiego. Zwolennicy Piaseckiego, którzy przeszedłszy często partyzancki szlak Uderzeniowych Batalionów Kadrowych Konfederacji Narodu, widzieli w nich atak na sens własnych poświęceń ${ }^{8}$. Być może oddziaływała ona na tę cześć grupy, która $z$ Piaseckim związała się dopiero po wojnie. Jej przedstawicielem był Andrzej Micewski, który stwierdzał, że Pamflety... wywarły znaczący wpływ na młodych działaczy „Dziś i Jutro”. Sam Piasecki nie chciał opierać ideologii swojego ruchu tylko na czystym pragmatyzmie, pragnac przydać mu również silny pierwiastek ideowy ${ }^{10}$. Bocheński wspominał, że przywódca „Ruchu nienazwanego” i jego zwolennicy nawiązywali do tradycji powstańczych, gloryfikując insurekcje. Nie chcieli oni widzieć związku między przeszłością a współczesnościa, toteż mimo że doceniali argumentację geopolityczna Bocheńskiego, nie zezwolili nigdy na druk książki pod auspicjami swego środowiska. Publicysta na marginesie tej sprawy konkludował, że Piasecki i jego towarzysze byli w pewnym sensie romantykami ${ }^{11}$.

Pamflety wpisywały się w tendencje, które obok Bocheńskiego najgłośniej wyrażali Edmund Osmańczyk w Sprawach Polaków ${ }^{12}$ i Ksawery Pruszyński w Margrabim Wielopolskim ${ }^{13}$. Celem prezento-

$\overline{\text { przeprowadzona przez Jana Engelgarda”, Archiwum Katolickiego Stowarzysze- }}$ nia Civitas Christiana [dalej: AKSCCh], Zespół Akt dotyczących Aleksandra Bocheńskiego, sygn. I/12, bp; A. Garlicki, Z tajnych archiwów, Warszawa 1993, s. $25-29$.

7 S. Kisielewski, Bocheńscy i Bocheński, „Tygodnik Powszechny” 1975, nr 39, s. 12.

${ }^{8}$ Samo powołanie Konfederacji Narodu, do której weszła bliska Bocheńskiemu grupa „Wawel”, wzbudziło jego niechęć. Wspominał, że fakt powstania organizacji, nawiązującej w nazwie do zgubnej w jego optyce konfederacji barskiej, skłonił go do pracy nad Dziejami głupoty... jako książki przestrzegającej przed szkodliwymi wzorcami. O głupocie raz jeszcze. Rozmowa z Aleksandrem Bocheńskim, „Sztandar Młodych" 1986, nr 90, s. 1.

9 A. Micewski, Katolicy $w$ potrzasku. Wspomnienia z peryferii polityki, Warszawa 1993, s. 27.

10 J. Engelgard, Bolesław Piasecki 1939-1956, Warszawa 2015, s. 157-158.

11 „Moje spotkanie z Bolesławem...”, AKSCCh, Zespół Akt dotyczących Aleksandra Bocheńskiego, sygn. I/12, bp.

12 E. Os mańczyk, Sprawy Polaków, Katowice 1946.

${ }^{13}$ K. Pruszyńs ki, Margrabia Wielopolski, Warszawa 1946. 
wanego tu tekstu jest analiza publicystycznych reakcji na książkę, obrazujących nie tylko to, jak rozmaite polskie środowiska polityczne oceniały koncepcję ugody inteligencji katolickiej $z$ komunistami, lecz także realistyczne, nawiązujące do refleksji krakowskiej szkoły historycznej, historiograficzne oceny Bocheńskiego. Zwrócono uwage zarówno na teksty wpisujacce się w paradygmat historiografii marksistowskiej, artykuły, których autorzy zwiąani byli ze środowiskami katolików świeckich, jak i recepcję książki w prasie emigracyjnej. Kwerenda archiwalna pozwoliła na odnalezienie niepublikowanej recenzji autorstwa Jana Stanisława Łosia, korespondencji Bocheńskiego $z$ Jerzym Giedroyciem i Stanisławem Catem-Mackiewiczem, w której ci ostatni poddali pracę Bocheńskiego krytyce, oraz oceny książki sformułowaną w Ministerstwie Bezpieczeństwa Publicznego.

W publikacji wyróżnić można trzy zasadnicze osie narracyjne. Pierwsza wynika $z$ wyraźnego przekonania Bocheńskiego o wpływie historyków (a tych definiuje zarówno jako naukowców, jak i publicystów historycznych) na opinię publiczną oraz polityków. Jeśli historycy propagują błędne koncepcje polityczne, przyjmuje je także naród, co prowadzi go do kolejnych klęsk - konstatował Bocheński. Zdaniem publicysty owe zgubne tendencje wyrażały sie w braku realistycznego podejścia do polityki, rozumianej jako gra interesów, na którą wpływają co prawda czynniki emocjonalne, ale w której nie maja one decydujaccego znaczenia. Polityka narodowa powinna być zatem prowadzona jedynie na podstawie rozumowych przesłanek i racjonalnym rachunku sił własnych i obcych. Przekonanie o nadrzędności politycznego realizmu w polityce międzynarodowej stanowiło drugą oś Dziejów głupoty... Ostatnią było przełożenie dwóch powyższych na warunki polskie. Posłużyła temu analiza koncepcji historyków dotyczących polityki Stanisława Augusta Poniatowskiego, dziejów sprawy polskiej w dobie napoleońskiej oraz, w mniejszym stopniu, w epoce powstań narodowych. Była ona równocześnie wyrazem poglądów Bocheńskiego na te kwestie. Publicysta wyrażał przekonanie, że źródłem narodowych klęsk było lekceważenie przez polskich przywódców zasady, według której należało za wszelka cenę zapobiec zbliżeniu Rosji i Prus (Niemiec), które zawsze musiało przybrać charakter antypolski. Dodać należy, że koncepcję tę Bocheński propagował już przed wojna na łamach „Buntu Młodych” i wileńskiego „Słowa”. Niemniej wówczas, jak wspomniano, oznaczała ona głoszenie konieczności 
współpracy z Berlinem. Tymczasem Pamflety dziejopisarskie... sa apologia koncepcji ugody polsko-rosyjskiej i krytyka wszelkiej wiary w pomoc mocarstw zachodnich. Najważniejszym bohaterem książki jest zatem król Stanisław August, zdaniem Bocheńskiego najinteligentniejszy polski władca, któremu rodacy uniemożliwili przeprowadzenie Rzeczypospolitej przez skomplikowane uwarunkowania międzynarodowe ostatnich dekad XVIII w. W dobie napoleońskiej Polacy ślepo wierzyli Napoleonowi, przede wszystkim na skutek zupełnie irracjonalnego zjawiska, jakim było powstanie Księstwa Warszawskiego, wynikłe $z$ błyskotliwej kariery genialnego Korsykanina. Jedynie książę Adam Jerzy Czartoryski i jego zwolennicy zdawali sobie sprawę, twierdził publicysta, że jeszcze przed $1812 \mathrm{r}$. Polacy powinni opowiedzieć się po stronie cara Aleksandra I, który pragnął odbudować Polskę pod swym berłem w zamian za wsparcie $\mathrm{w}$ walce $\mathrm{z}$ cesarzem Francuzów. Nawet jednak po kongresie wiedeńskim okrojone Królestwo Polskie miało szerokie perspektywy polityczne, które jednak zostały zmarnotrawione powstaniami listopadowym i styczniowym. Wszystko to wydarzyło się, reasumował Bocheński, na skutek rozpowszechnienia w narodzie polskim „głupoty”, za które obarczał historyków. Stwierdzał, że wobec apologii koncepcji insurekcyjnych w II Rzeczypospolitej dziwić nie może, samobójcza jego zdaniem, polityka rządu RP na wychodźstwie i podziemia w kraju.

Nie jest też jednak niczym dziwnym, że koncepcje takie spotkać się musiały zwykle $z$ krytyka i nielicznymi jedynie ocenami pozytywnymi. Rozpatrzyć te opinie pragnę pod kątem stosunku do scharakteryzowanych trzech osi narracyjnych ksiazżki.

Przekonanie o wpływie historyków na opinię publiczną poddał na łamach „Dziś i Jutro” zdecydowanej krytyce Stefan Kieniewicz. Recenzent stwierdzał, że to dziejopisarstwo było odbiciem ducha epoki, nie zaś czynnikiem go kształtującym. Na niekorzyść argumentacji Bocheńskiego wpływało także to, że historyków, których wybrał na egzemplifikację swych poglądów, i ich dzieła trudno było zaliczyć do tych najpopularniejszych ${ }^{14}$. Podobnie sprawę ujmował Hieronim Pawicki, krytykując wysuwanie takich poglądów w obliczu zagrożenia rewizjonizmem niemieckim ${ }^{15}$. Stanisław K. Rostworowski jako jeden $z$ nielicznych recenzentów podkreślał $\mathrm{w}$ swej ocenie słuszność tezy Pamfletów dziejopisarskich o doniosłości

14 S. Kieniewicz, Nowy sąd nad historia, „Dziś i Jutro” 1947, nr 25, s. 1-2.

15 H. Pawicki, [list do redakcji], „Dziś i Jutro” 1947, nr 28, s. 12. 
narracji historycznych i konieczności obiektywnej pracy historyków, którzy w ocenie decyzji polityków powinni kierować się kryterium przysłużenia się przez nich celowi podniesienia zbiorowiska w hierarchii międzynarodowej. Stwierdzał, że nauczenie narodu myślenia politycznego to podstawowy warunek jego potęgi, co było szczególnie istotne wobec położenia geograficznego Polski ${ }^{16}$. Podobnie Jan Meysztowicz wskazywał, że błędna jego zdaniem polityka polskiego podziemia lat wojny $z$ jego najważniejsza decyzja - o rozpoczęciu powstania warszawskiego - była w dużej mierze skutkiem oddziaływana dziejopisarzy ${ }^{17}$.

Paweł Jasienica także kwestionował tezę o wpływie historyków na błędne decyzje. Wskazywał, że te miały miejsce jeszcze przed wiekiem XIX, w sytuacji gdy w Rzeczpospolitej tworzyło wielu wybitnych pisarzy politycznych. Naiwność polskich historyków, której nie przeczył, uważał za objaw faktycznych przyczyn upadku Rzeczpospolitej i późniejszych klęsk narodowych - braku silnego ośrodka władzy centralnej, który miał wpływ na zanik sztuki myślenia politycznego wśród elit. Podobnie polemizował z teza, według której staropolskie warcholstwo i anarchia, odpowiedzialne za rozbiory, nie miały wpływu na polska mentalność w wieku XIX. Bocheński miał zdaniem recenzenta lekceważyć znaczenie opinii mas w działaniach polityków. Dowodem na to była, afirmowana przez niego, polityka króla Stanisława Augusta, który swych zamierzeń nie zdołał przeprowadzić na skutek oporu rzesz mających wpływ na politykę państwa. Uważał więc Jasienica, że książka opowiada w istocie nie o tytułowej „głupocie”, lecz o braku realizmu politycznego, tym bardziej że ci, którym Bocheński głupotę przypisywał, często w innych miejscach przedstawiali tezy nader logiczne ${ }^{18}$. Na łamach „Tygodnika Warszawskiego” Irena Pannenkowa krytykowała Bocheńskiego w kontekście jego sprzeciwu wobec romantyzmu w historiografii, piszac o jego postawie przed 1939 r.: „czy sam wtedy też coś niecoś nie "tromtadrował"? Czy się tam troszkę "niepodległościowo" i "mocarstwowo" nie bałamucił?"19.

Jan Szczepański w „Kuźnicy” twierdził, że książka Bocheńskiego miała za zadanie udowodnić, iż Polacy sa narodem politycznie

16 S.K. Rostworows ki, O szkołe politycznego myślenia, „Dziś i Jutro” 1947, nr 28, s. 3-4.

17 J. Meys z towicz, Jeszcze „Dzieje głupoty”, „Dziś i Jutro” 1947, nr 22, s. 12.

18 P. J a s i en ica, Cień Machiawela, „Tygodnik Powszechny” 1947, nr 31, s. 6-7.

19 I. Pannenkowa, Mentorzy, „Tygodnik Warszawski” 1947, nr 49, s. 4. 
„głupim”, z powodu zgubnego na nich wpływu tytułowej „głupoty” historyków. Trafnie analizując tok myślowy Bocheńskiego, definiował owa "głupotę" jako niedostrzeganie oraz niewykorzystywanie koniunktur międzynarodowych. Podawał jednak recenzent w watpliwość tezę, że historycy mieli kompetencje i możliwości ku temu, aby na politykę realnie wpływać. Polacy mieli synonimicznie traktować historię i politykę, a historyków utożsamiać z przywódcami. Wielu dziejopisów było kiepskimi politykami, przyznawał Szczepański, ale dlatego, że nie znali danych, którymi kierowali się fachowi politycy ${ }^{20}$.

Spokojniej do tej części argumentacji Bocheńskiego podchodził Władysław Dziewanowski na łamach „Tek Historycznych”. Zauważał, że książkę Bocheńskiego determinuje przekonanie o potrzebie prawdy historycznej wolnej od uwarunkowań czy potrzeb narodowych ja zniekształcajacych ${ }^{21}$. Stanisław Cat-Mackiewicz w liście do Bocheńskiego zarzucał mu wręcz, że zbyt słabo wyświetlił wpływ „durniów” (np. mesjanistów) na uczonych, czyli historyków. Polski realizm, konstatował Cat, oznaczać musiał głoszenie niekiedy haseł głupich, podobających się społeczeństwu. Przeceniał także Bocheński jego zdaniem oddziaływanie Jędrzeja Giertycha i Michała Bobrzyńskiego ${ }^{22}$.

$\mathrm{Na}$ tle wszystkich tych tekstów wyróżnia się nieopublikowana recenzja autorstwa Stanisława Łosia. Autor podkreślał w niej szkodliwość ulegania woli opinii publicznej oraz brak w Polsce rzeczywistej szkoły myślenia politycznego. Zdaniem Łosia polityka zajmowali się w Polsce ludzie bez wiedzy i doświadczenia, podobnie jak ci, którzy rościli sobie prawa do kreowania politycznych dogmatów. Uznawał to za rzeczywista genezę, niewyświetlona przez publikację, tytułowego zjawiska „polskiej głupoty”. Narodowe odruchy i kompleksy były $\mathrm{w}$ tej sytuacji skutkiem raczej takiego stanu rzeczy. W głównej jednak ich tezie zgadzał się z Pamfletami: „prawda jest

${ }^{20}$ J. Szczepań ski, Czy naprawdę winni historycy?, „Kuźnica” 1948, nr 17, s. 7.

${ }^{21}$ W. Dziewanowski, O „Dziejach głupoty w Polsce”, „Teki Historyczne” 1948, t. II, nr 2, s. 69-79.

${ }^{22}$ List Stanisława Cata-Mackiewicza do Aleksandra Bocheńskiego, 15 V 1948, Archiwum Instytutu Pamięci Narodowej w Warszawie [dalej: AIPN], sygn. IPN BU 0648/74/1, k. 142-143. Bocheński w odpowiedzi na to pismo wskazywał, że pragnał przede wszystkim podkreślić negatywne oddziaływanie propagandy danych pogląów, nie zaś intencje ich autorów. [List Aleksandra Bocheńskiego do Stanisława Cata-Mackiewicza, Kraków 27 V 1948] S. Cat-Mackiewicz, Wunderkind. Rzecz o Adolfie Bocheńskim, Kraków 2017, s. 213-214. 
też, że historiografia polska takie nieoglądanie się na skutki w myśl nakazów "cnoty" przeważnie rozgrzeszała, gloryfikując ludzi, co nakazom tym byli posłuszni. Potomność gdy "księgę błędów czytać zasiadła spłakana" okazała iście macierzyńskie serce błądzącym. I doszło w końcu do tego, że gdy Polak zapragnał pozyskać w sercach rodaków pomnik trwalszy od spiżu, potrzebował, by ten cel osiagnać, jedynie związać swe nazwisko $z$ jakąś wielką narodowa katastrofą. Historia dobre chęci zapisywała jako zasługi"23.

Bocheński odniósł się do niektórych $z$ tez recenzentów, uznając, że sam padł ofiara nieporozumienia. Wyrażał on pogląd, że celowo skupiał się na autorach dzieł syntetycznych i publicystycznych, jako mających większą siłę oddziaływania na społeczeństwo niż monografie przyczynkarskie. Uderzał innymi słowy, faktycznie, jak pisał Szczepański, w dziejopisów uprawiających politykę, ale zaznaczał, że musiała to być polityka błędna. Uznawał jednocześnie, że snucie analogii historycznych przez historyków silnie wpływa na proces decydowania politycznego. Było to charakterystyczne zwłaszcza w warunkach polskich, gdzie przez dwa stulecia naród miał być pozbawiony wybitnych, fachowych decydentów ${ }^{24}$. Tak też intencje Bocheńskiego odczytywał autor wielce pochlebnej wobec niego recenzji, zamieszczonej na łamach „Odry”, Kazimierz Koźniewski. Zaznaczał on, że publicysta swą wściekłość na błędy polityki polskiej lat II wojny światowej, których przyczyn upatrywał w wychowaniu narodu przez romantyków-historyków, przenosił na cała insurekcyjna tradycję historiografii polskiej ${ }^{25}$.

$Z$ pewnościa Bocheński opierał swe rozważania na realizmie politycznym. Dodać należy, że definiował go jako kierowanie się racjonalną, pozbawiona wpływów emocjonalnych, analizą rzeczywistości i wyciaganiu $z$ niej wniosków dotyczących sfery publicznej. Realny musiał być nie tylko ogląd sytuacji, lecz także cele, środki i metody działania oraz granica kompromisu. Realizm polityczny, także w ujęciu Bocheńskiego, nie lekceważy wpływu czynników emocjonalnych na politykę, sam jednak stara się być na niego odporny. Uznaje jednocześnie znaczenie moralności w polityce, stwierdzając

23 „A. Bocheńskiego: "Dzieje głupoty w Polsce»”, APL, AŁN, sygn. 484, k. 2-5.

${ }^{24}$ A. B oc heńs ki, W sprawie „Dziejów głupoty”, „Kuźnica” 1948, nr 21, s. 11. Włodzimierz Dworzaczek tę odpowiedź Bocheńskiego uznawał za doskonałą. List Włodzimierza Dworzaczka do Aleksandra Bocheńskiego, Poznań 16 VI 1948, AIPN, sygn. IPN BU 0648/74/1, k. 171.

${ }^{25}$ K. Koźniewski, Na marginesie "Dziejów głupoty w Polsce", „Odra” 1947, nr 43-44, s. 6-7. 
jednak pesymistycznie konflikt między nią a działaniem dążącym do osiagnięcia politycznej korzyści. Ta ostatnia jednak wynika zwykle $z$ przyjęcia idealistycznego celu, jak np. interes narodowy ${ }^{26}$.

Realizm polityczny Bocheńskiego, widoczny w Dziejach głupoty..., rzucał wyzwanie całej polskiej tradycji romantyczno-insurekcyjnej. Nic też dziwnego, że także i on wzbudzał szeroką zwykle krytykę. Ów „namiętny apostoł realizmu politycznego”27, jak określał go Stefan Kisielewski, uznawany był jednak za przeciwnika poważnego, zdolnego naruszyć mit powstańczy. Andrzej Micewski przyznając, że „realizm krakowskiej szkoły historycznej jest mi bliższy niż wszyscy historyczni i polityczni romantycy”, zauważał: „Oczywiście, bez wieszczów XIX wieku i późniejszych romantyków Polska by nie istniała. Ale przez nasze powstania zbrojne istnieje bardzo od dwóch wieków osłabiona”28. „Kisiel” dopowiadał, że książka miała być „zakrakana” przez „formalistycznych, pedantycznych historyków", pokryta obojętnością lub niechęcia podrażnionych tytułem odbiorców ${ }^{29}$. Praca stanowiła jednocześnie „konieczne i zdrowe odciążenie dla powstańczego mistycyzmu, odciążenie jedynie skuteczne, bo politycznie nie podejrzane, wychodzace od autora nic wspólnego nie mającego $z$ akcja publicystyczną usiłującą kilku sloganami załatwić się $z$ ideologia krwi i ofiary"30.

Hieronim Pawicki na stronach „Dziś i Jutro” zarzucał Bocheńskiemu brak szerszej podbudowy historycznej, socjologicznej, filozoficznej i metodologicznej rozważań. Przeciwstawiał jego reali-

${ }^{26}$ Por. P. Kimla, Historycy-politycy jako źródło realizmu politycznego. Tukidydes - Polibiusz - Machiavelli, Kraków 2009; id e m, Etyka w realizmie politycznym, „Czasopismo Prawno-Historyczne” 2014, t. LXVI, z. 2, s. 303-314; id e m, Realistyczne krytyki moralizatorstwa w polityce, [w:] Moralność i władza jako kategorie myśli politycznej, red. J. Justyński, A. Madeja, Warszawa 2011, s. 13-22; P. Ki mla, Realizm polityczny a Polska, [w:] Między sercem a rozumem. Romantyzm i realizm w polskiej myśli politycznej, red. A. Citkowska-Kimla, P. Kimla, E. Antipow, K. Konik, Kraków 2017, s. 41-64; H.J. M orgen th a u, Polityka między narodami. Walka o potęge i pokój, Warszawa 2010.

27 S. Kisielewski, Pod włos... Znowu diabet, „Tygodnik Powszechny” 1946, nr 49, s. 12 .

28 A. Micews ki, Dziennik idacego samotnie (czerwiec 1993 - wrzesień 1998), Warszawa 1998, s. 53.

${ }^{29}$ S. Kisielewski, Gwoździe w mózgu. Świąteczna karuzela, „Tygodnik Powszechny” 1959, nr 52, s. 12; ide m, Bocheńscy i Bocheński, „Tygodnik Powszechny" 1975, nr 39, s. 12; idem, Trochę historii, [w:] ide m, Felietony, t. I (Rzeczy małe), Warszawa 2013, s. 276; id e m, Porzadek stary już się wali, [w:] id e m, Felietony..., s. 330.

30 I d e m, Z literackiego lamusa, Kraków 1979, s. 28. 
zmowi politycznemu „realizm historyczny”31. Najsilniej jednak racjonalizm Bocheńskiego zaatakowali Jerzy Braun i Paweł Jasienica. Uznawali, że autor Pamfletów... jest neopozytywistycznym wyznawca zasady „ani kropli krwi więcej”, lekceważącym znaczenie takich kwestii, jak statystyka ofiar, hekatomba krwi czy logika honoru narodowego ${ }^{32}$. Braun przyznawał, że Bocheński „rozróżnia bohaterstwo bezcelowe, dla straceńczego gestu, od bohaterstwa świadomego, w służbie rozumnej idei politycznej czy koncepcji strategicznej"33. Obaj publicyści krytykowali natomiast propagowane przez książkę ujęcie polityki jako brutalnej walki i odejście w niej od kwestii moralnych, co sprowadzać miało rzecz całą do machiawelizmu umiarkowanego, konserwatywnego. Nie miał być Bocheński zwolennikiem gwałtu czy zbrodni, ale nacjonalizmu i imperializmu, na który nie potrafiła się zdobyć przedrozbiorowa Rzeczpospolita i którego ofiara padła ${ }^{34}$. Postulując zasadę napadania na słabszego sąsiada, miał się stawiać poza współczesnymi tendencjami pokojowego unormowania świata i rozdzielać politykę od moralności chrześcijańskiej. Braun pisał: „pragnie jakoś pogodzić swój umiarkowany machiawelizm $z$ katolicyzmem (jest przecież publicznym reprezentantem grupy deklarującej się jako katolicka). Ale taka synteza dobra ze złem nie da się zrealizować" ${ }^{35}$. Recenzent wskazywał, że teza Górskiego, skrytykowana przez Bocheńskiego, iż moralność zwycięża ponad siłę, znajdowała odbicie w historii, w postaci zwycięstwa Rzymu nad Kartaginą czy Grecji nad Persją. Publicysta „Tygodnika Warszawskiego” stawiał wyżej prawo moralne nad logika, wskazując, że współcześnie to ono zaczyna rzeczywiście wygrywać w polityce. Powołując się na Mahatmę Gandhiego, twierdził, że wielkość narodu służyć powinna podniesieniu ludzkości, oraz zauważał, że tymczasem dla Bocheńskiego była ona celem

${ }^{31}$ H. Pawicki, op. cit., s. 12.

${ }^{32}$ J. Braun, Bronię romantyzmu, „Tygodnik Warszawski” 1948, nr 7, s. 1; P. Jasienica, op. cit., s. 6-7.

${ }^{33}$ J. Braun, Katolicyzm a machiawelizm, "Tygodnik Warszawski” 1948, nr 12 , s. 6.

${ }^{34}$ Zjawisko to krytykował Bocheński razem ze swym bratem Adolfem w swej pierwszej książce. A. Bocheński, A.M. Bocheński, Tendencje samobójcze narodu polskiego, Lwów 1925. Bocheński pisał też w odpowiedzi, że nie jest przeciwnikiem samej walki zbrojnej, ale takiej, która jest podejmowana w niekorzystnych okolicznościach. Wielokrotnie miał dowodzić potrzeby prowadzenia walk lepiej przygotowanych „od ruchawek, do których nasi przodkowie się ograniczyli”.

A. B och eński, List do redakcji, „Tygodnik Warszawski” 1948, nr 9, s. 8.

${ }^{35}$ J. Braun, Katolicyzm a machiawelizm..., s. 1. 
samym w sobie. Jak się wydaje, autor recenzji nie wykroczył poza dziewiętnastowieczny idealizm, nie zauważając, że ci, którzy górowali moralnie, mogli też górować swoim potencjałem ${ }^{36}$. Podobnie rzecz widział Jasienica, zdaniem którego Bocheński potępiał tych wszystkich, którzy w polityce kierowali się trzeźwo rozumianym interesem, nie zaś dążeniem do przyjęcia przez zbiorowisko wysokiej postawy moralnej ${ }^{37}$.

Krytyka marksistowska, którą reprezentowali Józef Dutkiewicz i Celina Bobińska, podkreślała sprzeczność realizmu Bocheńskiego $z$ tradycjami walki rewolucyjnej i narodowowyzwoleńczej. Realizm Bocheńskiego miał być krótkowzroczny, bowiem zdaniem recenzentów powstania odniosły sukces, prowadząc do współczesnej Polski Ludowej. Bobińska zauważała, że Bocheński snuje przez swą analizę argumentację historyczną dla "sojuszu” polsko-sowieckiego, niemniej zabiegi utrzymane w takiej tonacji uznawała za szkodliwe ${ }^{38}$. Ministerstwo Bezpieczeństwa Publicznego uznawało, prawdopodobnie na skutek powyższego, książkę Bocheńskiego jako antysowiecka ${ }^{39}$.

Irena Pannenkowa za błędną uznawała tezę, wyrażoną przez Bocheńskiego i K. Pruszyńskiego, jakoby wielkimi politykami mogli być przede wszystkim politycy skuteczni. Kryterium siły w polityce miało być tymczasem niepopularne wśród Polaków. Toteż: „Fakt, że tezy i wywody, zawarte w książkach Bocheńskiego i Pruszyńskiego zostały skrytykowane i odparte zarówno przez pisarzy obozu kato-

36 Ibidem, s. 6.

${ }^{37}$ P. Jasienica, op. cit., s. 6-7.

38 J. Dutkiewicz, Aleksander Bocheński: Dzieje głupoty w Polsce. Wyd. Panteon, Warszawa 1947, str. 330, „Myśl Współczesna” 1948, nr 4, s. 132-135; C. Bobińska, Tradycje i teraźniejszość, „Nowe Drogi” 1947, nr 4, s. 72-91. W innym miejscu, w 1950 r., Bobińska pisała, krytykując zwłaszcza pracę Adama Skałkowskiego o Aleksandrze Wielopolskim, ale także określone tendencje w historiografii polskiej: „racja stanu miała być polityka ugody z carską Rosjac. Mamy tutaj konserwatyzm krakowski jako "bazę naukową" dla lansowania endeckich świętości, a wszystko to w sosie odwiecznego i nieprzemijajacego konfliktu polsko-niemieckiego i zawsze jednakowej potrzeby "ugody z Rosją", to znaczy z caratem. Kilka lat temu tzw. "neopozytywiści katoliccy" wysuwali tę endecką koncepcję dowodzac, że Polska Ludowa jest... spadkobierczynią Wielopolskiego i Dmowskiego. Za cenę skompromitowania rewolucyjnego sojuszu Polski Ludowej z rewolucyjnym Związkiem Radzieckim chciano "pojednać" reakcyjne mieszczaństwo $z$ demokracją ludowa”. Ead e m, O przełom w nauce historycznej. Na marginesie narady historyków-marksistów, „Nowa Kultura” 1950, nr 2, s. 3.

39 „Charakterystyka Aleksandra Bocheńskiego”, AIPN, sygn. IPN BU 0648/ 74/1, k. 206. 
lickiego (Kieniewicz, Jasienica) jak i marksistowskiego (Bobińska), świadczy m. in., że nie znajduja one oparcia i odzewu w szerokich masach społeczeństwa. To powinno obu pisarzom dać do myślenia na przyszłość"40. Dodać należy, że obaj publicyści nie uznawali za jakikolwiek miernik wartości swych poglądów ich popularności.

Emocjonalnie do książki Bocheńskiego podchodził na łamach "Gazety Ludowej” „dr Wacław Reguła”, czyli były senator Wojciech Rostworowski. Publikacji zarzucał prymitywizm, lekceważenie i niewrażliwość na kwestie „honoru i sumienia”, samemu Bocheńskiemu zaś "amoralność", zaskakujaca u aktywnego działacza katolickiego. Bocheński miał jego zdaniem w tragizmie dziejów Polski widzieć jedynie "głupotę"

Jan Ulatowski na łamach emigracyjnej „Kultury” zarzucał Dziejom głupoty... zohydzanie Polakom idei własnej państwowości i lekceważenie geopolityki. Prawidła tej ostatniej miały według niego wymagać czynnego manifestowania narodowych praw $\mathrm{w}$ celu zachowania własnej tożsamości oraz budowania fałszywych nawet mitów. Zdaniem Ulatowskiego Polacy, gdyby przyjęli tezy Bocheńskiego, mogliby nie wykorzystać szans, jakie przyniosłaby dla nich możliwa III wojna światowa ${ }^{42}$. Władysław Dziewanowski w „Tekach Historycznych" spoglądał na problem głębiej, widząc w apologii ugody wyraz prymatu narodu nad państwem, co miało grozić negatywnymi skutkami politycznymi ${ }^{43}$. W londyńskich „Wiadomościach” Wiktor Weintraub, a w „Myśli Polskiej” Wojciech Wasiutyński zgodnie dowodzili, że Bocheński był bardziej spadkobierca krakowskiej szkoły historycznej niż Dmowskiego, dziedzicząc od tej pierwszej metodę oglądu relacji Polski z sąsiadami, a od drugiego - orientacje na Rosję. Dodatkowo zdaniem Weintrauba publicysta miał lekceważyć czynniki społeczno-ekonomiczne w celu wykazania nadrzędności polityki realnej w grze wielkich mocarstw. Wasiutyński i inne emigracyjne pismo narodowe, „Placówka”, twierdzili, że tacy realiści, jak Bocheński wkrótce przestaną być

${ }^{40}$ I. Pannenkowa, Mentorzy..., s. 4. Pannenkowa swoją krytykę realizmu politycznego w ocenie przeszłości rozwinęła już w 1946 r. Eade m, Czy nie za wiele pesymizmu?, „Tygodnik Warszawski” 1946, nr 34, s. 2.

${ }^{41}$ W. Reguła [W. Ros tworow s ki], Dzieje głupoty w Polsce, „Gazeta Ludowa” 1947, nr 180, s. 5 .

${ }^{42}$ J. Ula tow s ki, Dzieje gtupoty w Polsce, „Kultura” 1947, nr 2-3, s. 151-157.

${ }^{43}$ W. Dziewanowski, O "Dziejach głupoty w Polsce”, "Teki Historyczne” 1948, t. II, nr 2, s. 69-79. 
Sowietom potrzebni, gdyż Moskwa ma w polskich komunistach sprzymierzeńca nie koniunkturalnego, lecz ideowego. Narodowcy i Weintraub nie zarzucali Bocheńskiemu koniunkturalizmu, ale zupełnie błędny ogląd sytuacji ${ }^{44}$. Z kolei Koźniewski na łamach „Odry” przestrzegał przed przypisywaniem książce Bocheńskiego roli argumentacyjnej wobec współczesnej orientacji na Rosje, uznając przesłanie Dziejów głupoty za uniwersalne ${ }^{45}$.

Nie tylko błąd koncepcji, lecz także oportunizm i zdradę zarzucał za to Dziejom głupoty Adam Michnik, nazywając ja „manifestem zdrady". Monografia miała jasno definiować drogę Bocheńskiego jako „realisty” współpracującego $z$ komunistami. Sam tytuł publikacji Michnika $Z$ dziejów honoru $w$ Polsce stanowił nawiązanie do najsłynniejszej książki Bocheńskiego ${ }^{46}$.

$Z$ pewnością największe opory czytelników budził wykład dziejów Polski od epoki Stanisława Augusta po współczesność, zaproponowany przez Bocheńskiego. Zdaniem Jana Nepomucena Millera były to tezy tak szerokie i prowokacyjne, że każace domniemywać, iż wynikały nie $z$ pogłębionych badań źródłowych, lecz miały być skutkiem „metafizyki politycznej”. Recenzent, uznajac potrzebę „sojuszu” ze Związkiem Sowieckim, równocześnie zarzucał publicyście, że krytykując dzieje walki z Rosja carska, zohydza Polakom własna przeszłość. Przypisywał mu chęć wybielania reżimu carskiego kosztem większego pognębiania "głupoty” rodaków. Miller uznawał za słuszną krytykę konfederacji barskiej, polityki Sejmu Czteroletniego i tradycji insurekcyjnej, ale nie mogło to służyć apologii Katarzyny II czy Nikołaja Repnina. Tymczasem zdaniem recenzenta caryca była w optyce Bocheńskiego „niemal matka miłosierdzia dla znękanej przez Polaków Polski”. Miał być przy tym Bocheński niekonsekwentny - podnoszac konieczność walki z błędami ustroju, autor Pamfletów... krytykował Sejm Czteroletni. Miller uważał też, że polityka zapobiegania walce $z$ Rosja wcale nie musiała być w XVIII w. najlepsza, gdyż nikt jego zdaniem bezapelacyjnie nie dowiódł, że Rosja nie pragnęła rozbiorów Rzeczpospolitej. Zdaniem recenzenta Bocheński konstruował tezy

${ }^{44}$ W. Weintraub, Jak być madrym wobec Rosji, „Wiadomości” 1947, nr 31, s. 1; W. Wasiutyńs ki, Neougodowiec, „Myśl Polska” 1948, nr 7, s. 9; (m), Czy historycy sa odpowiedzialni za nasza polityke, „Placówka” 1948, nr 3, s. 3.

45 K. Koźniew ski, Na marginesie "Dziejów..., s. 6-7.

46 A. Michnik, $Z$ dziejów honoru $w$ Polsce. Wypisy więzienne, Paryż 1985, s. $159,169-170,190-191$. 
w sposób zbyt pewny siebie, a nie podparty merytorycznymi badaniami, stając się „rzecznikiem ministerialnym” i „propagandysta”. Jego refleksja była jednak potrzebna i ciekawa, i, jeśli zarzuciłby podejście „teologiczne” i „metafizyczne”, mógłby stać się znakomitym historykiem ${ }^{47}$. $Z$ satysfakcja te krytyczne rozważania przytaczała „Gazeta Ludowa”48.

Kieniewicz uważał, że niekiedy krytykowana przez Bocheńskiego "głupota” była tożsama $z$ racją stanu. Powątpiewał w niechęć Rosji do rozbiorów Rzeczpospolitej ${ }^{49}$. Także zdaniem Dziewanowskiego polityka oparcia się na Rosji była ryzykowna - jego zdaniem wszelkie próby ugody upadały $z$ winy rosyjskiej. Trudno zgodzić się $z$ opinia, że publicysta lekceważył jako czynnik wpływający na upadek Polski wzrost siły sąsiadów (Bocheński był wyznawca zasady relatywizmu politycznego, głoszącej, że potęga państwa jest zależna przede wszystkim od potencjałów państw sąsiednich) ${ }^{50}$. Ulatowski widział natomiast w krytykowanym przez Bocheńskiego liberum veto przejaw polskiego instynktu wolności. Podobnie ujmował polskie powstania, uważając, że „elektryzując naród”, nie pozwalały zapomnieć o dążeniu do niepodległości, a przez to w końcu ją odzyskać ${ }^{51}$. Szczególnie ostro zaatakowała narrację Bocheńskiego „Placówka”, nawiązując do międzywojennej przeszłości autora publikacji. Przypominano "mocarstwowy” program jego i grupy Giedroycia, krytykę postanowień traktatu ryskiego jako odbierającego Polsce szerokie obszary kresowe. Tymczasem, przypominano, po II wojnie światowej Bocheński stał się apologetą linii Curzona. Sama książka miała być reakcją na klęskę w 1939 r. i skutkiem krytycznego oglądu „tromtadracji piłsudczyków”, z czasem jednak autor zabarwił ją czerwonym atramentem ${ }^{52}$.

Dutkiewicza bulwersowały wnioski Bocheńskiego, które musiały prowadzić do krytyki rewolucji 1905 r., a pochwały - udziału

47 J.N. Mille r, „Tym gorzej dla faktów!”, „Warszawa” 1947, nr 10, s. 2.

48 Przeglad prasy literackiej. Historia, opozycja, postęp, „Gazeta Ludowa” 1947, nr 256, s. 5.

49 S. Kieniewicz, op. cit., s. 1-2.

50 W. Dziewanowski, op. cit., s. 69-79.

51 J. Ulatowski, op. cit., s. 151-157.

52 (m), op. cit., s. 3. Jerzy Giedroyc tekst ten uznawał w liście do Bocheńskiego za bulwersujący. Redaktor „Kultury” uznawał jednak Dzieje głupoty... za książkę „straszna”. List Jerzego Giedroycia do Aleksandra Bocheńskiego, 11 III 1948, AIPN, sygn. IPN BU 0648/74/1, k. 107; List Jerzego Giedroycia do Aleksandra Bocheńskiego, 19 VII 1948, ibidem, k. 168-169. 
Polaków w rosyjskiej Dumie. Oburzało go też określanie Edwarda Dembowskiego mianem „wariata" ${ }^{3}$. Bobińska historyczne poglądy Bocheńskiego wprost określała jako „reakcyjne” ${ }^{54}$.

Do Dziejów głupoty... nawiązał Stanisław Stomma w swym głośnym artykule Dostęp do Polski współczesnej. Szukał w nich argumentacji historycznej dla programu porozumienia ze Zwiazkiem Sowieckim w dobie przemian październikowych ${ }^{55}$. Charakterystyczne, że po raz kolejny negatywnie na tę koncepcję zareagowała Irena Pannenkowa, wysuwając przy okazji pogląd, że Polska powinna „iść u boku Rosji” wtedy, kiedy Bocheński tego nie postulował, tj. w okresie obu wojen światowych ${ }^{56}$. Uznawała też wcześniej, że Bocheński był niekonsekwentny - krytykując powstania, jednocześnie pozytywnie przedstawiał Józefa Piłsudskiego, apologetę tradycji insurekcyjnej ${ }^{57}$.

Dyskusję na łamach czasopisma „Rzeczywistość” wzbudziło wznowienie książki w 1984 r. Hubert Kozłowski w swojej recenzji podkreślał słuszność krytyki powstań narodowych jako nieracjonalnych oraz przekonanie Bocheńskiego o rozumieniu racji stanu jako dążeniu do rozwoju narodowego. Postulował za Bocheńskim wychowywanie narodu $\mathrm{w}$ duchu realizmu i rozsadku ${ }^{58}$. W odpowiedzi Piotr Wagiel powoływał się na uczucie narodu, który szanować miał powstańców, nie zaś realistów, traktując to jako ważący argument ${ }^{59}$.

Odnosząc się do tej polemiki, Bocheński nie wdawał się w jej szczegółową analizę, wskazując jednak, że wielokrotnie domagał się szacunku dla walczących i poległych, także w imię narodowych interesów i racjonalnego, patriotycznego wychowania. Jego krytycy chcieli jednak rozciągnąć ten kult na decydentów, on zaś domagał się rozgraniczenia oceny owych dwóch zespołów ludzkich. Stwierdzał zresztą, że książka swą argumentacją broni się sama ${ }^{60}$.

53 J. Dutkiewicz, op. cit., s. 132-135.

${ }^{54}$ C. Bobińska, Tradycje i teraźniejszość..., s. 72-91.

55 S. Stomma, Dostęp do Polski współczesnej, „Przegląd Kulturalny” 1956, nr 43, s. 6-7.

${ }^{56}$ I. Pannenkowa, Historia mistrzynia życia ale tylko prawdziwa. O racji stanu, ideologii, oraz mądrości i głupocie politycznej, „Przegląd Kulturalny” 1957, nr 12, s. 1, 8-9.

57 Eadem, Mentorzy..., s. 3-4.

58 H. Kozłowski, Powrót „Dziejów głupoty”, „Rzeczywistość” 1984, nr 36, s. 6-7; i d e m, Rozum przeciwko głupocie, „Rzeczywistośc”” 1984, nr 45, s. 4-5.

59 P. Wagi iel, Podzwonne dla głupoty, „Rzeczywistość” 1984, nr 41, s. 7.

60 A. B o ch eń s ki, Książka obroni się sama..., „Rzeczywistość” 1984, nr 45, s. 4. 
Polemika na łamach „Rzeczywistości” była jednak pogłosem sporów $z$ lat czterdziestych, o czym dobitnie świadczyły też recenzje zamieszczone w „Polityce"61, „Tu i teraz"62, „Perspektywach"63 i „Nowych Książkach" ${ }^{64}$. W latach dziewięćdziesiątych jeden $z$ recenzentów $z$ kolei nazywał odbiór książki Bocheńskiego „Dziejami głuchoty”, co dobrze oddawało przemilczenie ostatniego wydania tej pracy ${ }^{65}$.

Książka wzbudziła także wiele odniesień w historiografii i publicystyce niewyrażających się w formie artykułów recenzenckich, ale odniesień. Nawiązania do tytułowej „głupoty w Polsce”, czy częściej „głupoty polskiej” (co było jednak wypaczeniem sensu stwierdzenia), pojawiały się w formie częstokroć pejoratywnej dla Bocheńskiego w szeregu prac ${ }^{66}$.

Andrzej F. Grabski zauważał, że Bocheński w swej książce nawiązywał do koncepcji Henryka Barycza postulujacej krytyczny ogląd tradycji insurekcyjnej i jagiellońskiej. Zauważał też, że krytyka marksistów wobec tych koncepcji rychło stała się przebrzmiała, a tezy Bocheńskiego przeniknęły do wspieranej przez rządzących Polska Ludowa refleksji historycznej ${ }^{67}$.

Jak się wydaje, zgodzić się można jednak z opinią, wyrażoną w 1970 r. przez Józefa Lewandowskiego, że książka Bocheńskiego ,jest to nadal jedna $z$ najbardziej inspirujacych, zmuszajacych do myślenia lektur ostatniego ćwierćwiecza, [...] polska myśl polityczna i historiozoficzna byłaby bez tej pracy o wiele uboższa"68. Bocheński krytykował błędne decyzje, nie zaś poświęcenie i męstwo walczących, wielokroć podkreślając konieczność rozróżnienia tych dwóch kwestii. Realizm oznaczał dla niego trzeźwą ocenę uwarun-

${ }^{61}$ A. Mozołows ki, Dzieje głupoty nieśmiertelnej, „Polityka” 1984, nr 44, s. 5.

${ }^{62}$ K. Koźniewski, Zamek, „Tu i teraz” 1984, nr 37, s. 1, 9.

${ }^{63}$ J. Koprows ki, Zgoda i niezgoda, „Perspektywy” 1984, nr 39, s. 24.

${ }^{64}$ J. Michalski, Grzechy sprzed lat, „Nowe Książki” 1984, nr 9, s. 13-16.

65 K. Koźniew s ki, Najnowsze wydanie ksiażki Aleksandra Bocheńskiego znowu przechodzi bez echa. Dzieje głuchoty w Polsce, „Wiadomości Kulturalne” 1997, nr 2, s. 7.

${ }^{66}$ Por. Żałosny mit realizmu. $Z$ prof. Andrzejem Nowakiem, historykiem, publicysta rozmawia Marcin Makowski, „Do Rzeczy” 2017, nr 16, s. 69-71; R.A. Zi e mki ew i cz, Złowrogi cień Marszałka, Lublin-Warszawa 2017, s. 224.

${ }^{67}$ A.F. Grabski, Orientacje polskiej myśli historycznej. Studia i rozważania, Warszawa 1972, s. 39-43; H. B a ry c z, O nowe drogi historiografii polskiej, „Nauka i Sztuka" 1946, t. II, s. 324-335.

68 J. Lew and ow s ki, "Dzieje przemysłu” Aleksandra Bocheńskiego, „Kultura” 1970, nr 9, s. 131-132. 
kowań przez decydentów. Żołnierze jednak, czy szerzej - naród, powinni bezwzględnie wysłuchiwać rozkazów przywódców. Rzecz w tym, argumentował publicysta, ażeby rozkazy te były oparte na trzeźwej analizie sytuacji międzynarodowej. Częstokroć zresztą narodowi przywódcy - Stanisław August czy margrabia Wielopolski - podejmowali decyzje słuszne, które jednak sabotowane były przez uniesione „frazesowym patriotyzmem” masy ${ }^{69}$.

Zdaniem Kisielewskiego Bocheński planował przygotowanie drugiej części Dziejów głupoty... pt. „Kraina wielkich błaznów”, z rozdziałami: „Mickiewicz”, "Chopin”, „Osterwa”70. Tytuł ten interpretować można dwojako - zarówno jako krytykę rozumowania politycznego w narodzie polskim, jak i apologię „wielkich błaznów” - stańczyków. Bocheński, odwołując się po wielokroć do dorobku krakowskiej szkoły historycznej i jej spadkobierców, mógł tytułem projektowanej książki wskazywać, że w zasadzie jedynie tradycje stańczykowskie były w polskiej myśli politycznej i historycznej godne miana „wielkości”, w przeciwieństwie do tendencji najbardziej rozpowszechnionych i dominujacych.

Niezależnie od tego książka Bocheńskiego spełniła przynajmniej jeden ze swych celów - wzbudzenie debaty na temat granic realizmu $\mathrm{w}$ polityce polskiej. Wpisywała się w wielowiekowy spór o koncepcje polityki zagranicznej w warunkach utraty niepodległego bytu państwowego i modelu zabiegów o jego przywrócenie ${ }^{71}$. Opublikowana w specyficznych warunkach politycznych, chciała także przekonać odbiorców do słuszności koncepcji porozumienia $z$ komunistami, w której Bocheński widział nawiązanie do tradycji dziewiętnastowiecznych pozytywistów, zarówno stańczyków, jak

${ }^{69}$ Por. A. Bocheński, Rozmyślania krytyczne. Bład Zbigniewa Florczaka, „Kierunki” 1956, nr 2, s. 1; ide m, Analiza polityczna artykułu Jerzego Łojka, „Kierunki” 1958, nr 1, s. 7; ide m, Drugi artykuł o margrabim, „Kierunki” 1958, nr 11 , s. 1.

70 S. Ki sielew ski, Gwoździe w mózgu. Świąteczna..., s. 12; i d e m, Bocheńscy $i$ Bocheński..., s. 12. Refleksje o Bocheńskim $z$ tego ostatniego tekstu przywoływano także na łamach londyńskich „Wiadomości”. Glos a tor, Z czasopism krajowych, „Wiadomości” 1975, nr 50, s. 5. O projekcie „Krainy wielkich błaznów” pisał do Cata już w 1948 r., stwierdzając jednak, że nie napisze go, nie chcąc złościć „naszych małych błaznów”. [List Aleksandra Bocheńskiego do Stanisława Cata-Mackiewicza, Kraków 27 V 1948], S. Cat-Mackiewicz, Wunderkind..., s. 215.

${ }^{71}$ Zdaniem Adama Bromkego spór między romantyzmem a realizmem był konstytutywny dla polskiej myśli politycznej ostatnich wieków. A. Bromke, Poland's Politics. Idealism vs Realism, Cambridge 1967. 
i ideowych spadkobierców margrabiego Wielopolskiego. Koncepcje Bocheńskiego spotykały się $z$ potępieniem zarówno komunistów, katolików świeckich, jak i emigracji niepodległościowej, znajdującej zrozumienie wśród nielicznej grupy pokrewnych mu ideowo publicystów.

\section{Bibliografia}

\section{Ź Ródea ARChIWALNE}

Archiwum Instytutu Pamięci Narodowej w Warszawie [AIPN] sygn. IPN BU 0648/74/1.

Archiwum Katolickiego Stowarzyszenia Civitas Christiana [AKSCCh]

Zespół Akt dotyczących Aleksandra Bocheńskiego, sygn. I/12.

Archiwum Państwowe w Lublinie [APL]

Archiwum Łosiów z Niemiec [AŁN], sygn. 463, 484.

\section{Ź RÓDEA DRUKOWANE}

Garlicki A., Z tajnych archiwów, Warszawa 1993.

\section{Publicystyka}

Bobińska C., O przełom $w$ nauce historycznej. Na marginesie narady historyków- marksistów, „Nowa Kultura” 1950, nr 2, s. 3.

Bobińska C., Tradycje i teraźniejszość, „Nowe Drogi” 1947, nr 4, s. 72-91.

Bocheński A., „Amocklauf”, „Polityka” 1939, nr 15, s. 1.

Bocheński A., Analiza polityczna artykułu Jerzego Łojka, „Kierunki” 1958, nr 1, s. 6-7.

Bocheński A., Drugi artykuł o margrabim, „Kierunki” 1958, nr 1, s. 1-2, 5, 7.

Bocheński A., Dzieje głupoty w Polsce. Pamflety dziejopisarskie, Warszawa 1947.

Bocheński A., Książka obroni się sama..., „Rzeczywistość” 1984, nr 45, s. 4.

Bocheński A., List do redakcji, „Tygodnik Warszawski” 1948, nr 9, s. 8.

Bocheński A., Motywy i postawy [Wypowiedź Aleksandra Bocheńskiego], „Kierunki" 1970, nr 48, s. 8.

Bocheński A., O imperialiźmie, o Skiwskim i o sprawie żydowskiej, „Polityka” 1938, nr 9, s. 3.

Bocheński A., Rozmyślania krytyczne. Błą Zbigniewa Florczaka, „Kierunki” 1956, nr 2, s. 1, 12.

Bocheński A., W sprawie „Dziejów głupoty”, „Kuźnica” 1948, nr 21, s. 11. 
Bocheński A., Wędrówki po dziejach przemysłu polskiego, cz. 2, Warszawa 1969.

Bocheński A., Zygzakiem przez prasę. Prasa polska po hańbie czeskiej, „Polityka” 1939, nr 6, s. 8.

Bocheński A., Bocheński A.M., Tendencje samobójcze narodu polskiego, Lwów 1925.

Braun J., Bronię romantyzmu, „Tygodnik Warszawski” 1948, nr 7, s. 1.

Braun J., Katolicyzm a machiawelizm, „Tygodnik Warszawski” 1948, nr 12, s. 1, 6.

Cat-Mackiewicz S., Wunderkind. Rzecz o Adolfie Bocheńskim, Kraków 2017.

Dutkiewicz J., Aleksander Bocheński: Dzieje głupoty w Polsce. Wyd. Panteon, Warszawa 1947, str. 330, „Myśl Współczesna” 1948, nr 4, s. 132-135.

Dziewanowski W., O „Dziejach głupoty w Polsce”, „Teki Historyczne” 1948, t. II, nr 2, s. 69-79.

Glosator, Z czasopism krajowych, „Wiadomości” 1975, nr 50, s. 5.

Grabski A.F., Orientacje polskiej myśli historycznej. Studia i rozważania, Warszawa 1972.

Jasienica P., Cień Machiawela, „Tygodnik Powszechny” 1947, nr 31, s. 6-7.

Kieniewicz S., Nowy sad nad historia, „Dziś i Jutro” 1947, nr 25, s. 1-2.

Kisielewski S., Bocheńscy i Bocheński, „Tygodnik Powszechny” 1975, nr 39, s. 12.

Kisielewski S., Felietony, t. I (Rzeczy małe), Warszawa 2013.

Kisielewski S., Gwoździe w mózgu. Świąteczna karuzela, „Tygodnik Powszechny” 1959, nr 52, s. 12.

Kisielewski S., Pod włos... Znowu diabeł, „Tygodnik Powszechny” 1946, nr 49, s. 12.

Kisielewski S., Z literackiego lamusa, Kraków 1979.

Koprowski J., Zgoda i niezgoda, „Perspektywy” 1984, nr 39, s. 24.

Kozłowski H., Powrót „Dziejów głupoty”, „Rzeczywistość” 1984, nr 36, s. 6-7.

Kozłowski H., Rozum przeciwko głupocie, „Rzeczywistość” 1984, nr 45, s. 4-5.

Koźniewski K., Na marginesie "Dziejów głupoty w Polsce", „Odra” 1947, nr 43-44, s. 6-7.

Koźniewski K., Najnowsze wydanie książki Aleksandra Bocheńskiego znowu przechodzi bez echa. Dzieje głuchoty w Polsce, „Wiadomości Kulturalne” 1997, nr 2, s. 7 .

Koźniewski K., Zamek, „Tu i teraz” 1984, nr 37, s. 1, 9.

Lewandowski J., "Dzieje przemysłu” Aleksandra Bocheńskiego, „Kultura” 1970, nr 9, s. 131-135.

(m), Czy historycy sa odpowiedzialni za nasza politykę, „Placówka” 1948, nr 3, s. 3.

Meysztowicz J., Jeszcze „Dzieje głupoty”, „Dziś i Jutro” 1947, nr 22, s. 12.

Micewski A., Dziennik idącego samotnie (czerwiec 1993 - wrzesień 1998), Warszawa 1998.

Micewski A., Katolicy $w$ potrzasku. Wspomnienia $z$ peryferii polityki, Warszawa 1993.

Michalski J., Grzechy sprzed lat, „Nowe Książki” 1984, nr 9, s. 13-16.

Michnik A., Z dziejów honoru w Polsce. Wypisy więzienne, Paryż 1985. 
Miller J.N., „Tym gorzej dla faktów!”, „Warszawa” 1947, nr 10, s. 2.

Mozołowski A., Dzieje głupoty nieśmiertelnej, „Polityka” 1984, nr 44, s. 7.

Nie widze wzrostu racjonalnych postaw... Z Aleksandrem Bocheńskim $w$ 85-lecie urodzin rozmawia Karol Pastuszewski, „Kierunki” 1989, nr 33, s. 1, 7.

O głupocie raz jeszcze. Rozmowa z Aleksandrem Bocheńskim, „Sztandar Młodych” 1986, nr 90, s. $1,3$.

Osmańczyk E., Sprawy Polaków, Katowice 1946.

Pannenkowa I., Czy nie za wiele pesymizmu?, „Tygodnik Warszawski” 1946, nr 34, s. 2.

Pannenkowa I., Historia mistrzynia życia ale tylko prawdziwa. O racji stanu, ideologii, oraz mądrości i głupocie politycznej, „Przegląd Kulturalny” 1957, nr 12, s. $1,8-9$.

Pannenkowa I., Mentorzy, „Tygodnik Warszawski” 1947, nr 49, s. 3-4.

Pawicki H., [list do redakcji], „Dziś i Jutro” 1947, nr 28, s. 12.

Pruszyński K., Margrabia Wielopolski, Warszawa 1946.

Przeglad prasy literackiej. Historia, opozycja, postęp, „Gazeta Ludowa” 1947, nr 256, s. 5.

Reguła W. [Rostworowski W.], Dzieje głupoty w Polsce, „Gazeta Ludowa” 1947, nr 180, s. 5.

Rostworowski S. K., O szkołe politycznego myślenia, „Dziś i Jutro” 1947, nr 28, s. $3-4$.

Stomma S., Dostęp do Polski współczesnej, „Przegląd Kulturalny” 1956, nr 43, s. 6-7.

Szczepański J., Czy naprawdę winni historycy?, „Kuźnica” 1948, nr 17, s. 7.

Ulatowski J., Dzieje głupoty w Polsce, „Kultura” 1947, nr 2-3, s. 151-157.

Wasiutyński W., Neougodowiec, „Myśl Polska” 1948, nr 7, s. 9.

Wagiel P., Podzwonne dla głupoty, „Rzeczywistość” 1984, nr 41, s. 7.

Weintraub W., Jak być mąrym wobec Rosji, „Wiadomości” 1947, nr 31, s. 1.

Ziemkiewicz R.A., Złowrogi cień Marszałka, Lublin-Warszawa 2017.

Żałosny mit realizmu. Z prof. Andrzejem Nowakiem, historykiem, publicysta rozmawia Marcin Makowski, „Do Rzeczy” 2017, nr 16, s. 69-71.

\section{OpRacowania}

Barycz H., O nowe drogi historiografii polskiej, „Nauka i Sztuka” 1946, t. II, s. 324-335.

Bromke A., Poland's Politics. Idealism vs Realism, Cambridge 1967.

Engelgard J., Bolesław Piasecki 1939-1956, Warszawa 2015.

Górny M., Przede wszystkim ma być naród. Marksistowskie historiografie w Europie środkowo-wschodniej, Warszawa 2007.

Grabski A.F., Orientacje polskiej myśli historycznej. Studia i rozważania, Warszawa 1972. 
Kimla P., Etyka $w$ realizmie politycznym, „Czasopismo Prawno-Historyczne” 2014, t. LXVI, z. 2, s. 303-314.

Kimla P., Historycy-politycy jako źródło realizmu politycznego. Tukidydes - Polibiusz-Machiavelli, Kraków 2009.

Kimla P., Realistyczne krytyki moralizatorstwa w polityce, [w:] Moralność i władza jako kategorie myśli politycznej, red. J. Justyński, A. Madeja, Warszawa 2011, s. 41-64.

Kimla P., Realizm polityczny a Polska, [w:] Między sercem a rozumem. Romantyzm i realizm $w$ polskiej myśli politycznej, red. A. Citkowska-Kimla, P. Kimla, E. Antipow, K. Konik, Kraków 2017, s. 41-64.

Morgenthau H.J., Polityka między narodami. Walka o potegge i pokój, Warszawa 2010.

Mozgol R., Ryzykowna gra. Jak Aleksander Bocheński przyczynił się do powstania Dziś i Jutro, „Biuletyn Instytutu Pamięci Narodowej” 2007, nr 4, s. 84-92.

Stobiecki R., Historiografia PRL. Ani dobra, ani mądra, ani piękna... Ale skomplikowana, Warszawa 2007.

Ariel Orzelek

\title{
The journalistic reaction to the first edition of The History of Stupidity in Poland. The historiographic pamphlets by Aleksander Bocheński
}

\begin{abstract}
$T$ he History of Stupidity in Poland. The historiographical pamphlets was the most important publication by Aleksander Bocheński. It was also one of the most representative reflections on the postwar trend of political realism in Poland. The journalistic reception of the first edition of this book in the 1940s proved the unpopularity of the thesis included in its contents. Criticism of insurrection trends in the Polish politics by the author met with opposition from both Marxists, non-party intellectuals in the country and on the emigration. Although the motives of Bocheński's concepts were usually understood, they were rejected because they: serve the communists, are contrary to the Marxist doctrine or have not any moral foundation. These opinions constitute an important contribution to the views of the Polish intelligentsia on the political realism at the threshold of the Polish People's Republic.
\end{abstract}

Keywords: Aleksander Bochenski, historiography, journalism, political realism. 